\title{
Analysis of Sustainable Business Models: Exploratory Study in Two Brazilian Logistics Companies
}

\author{
Jaqueline Geisa Cunha Gomes ${ }^{1}$, Marcelo Tsuguio Okano ${ }^{1, * \mathbb{C}}$, Rodrigo Salgado Guerra ${ }^{2}$, \\ Denilson de Sousa Cordeiro ${ }^{1}$, Henry Castro Lobo dos Santos ${ }^{3}$ and Marcelo Eloy Fernandes ${ }^{1}$
}

1 CEETEPS—Centro Paula Souza, São Paulo 01208-000, Brazil; jaqueline.gomes@cpspos.sp.gov.br (J.G.C.G.); denilson.cordeiro@cpspos.sp.gov.br (D.d.S.C.); marceloeloyfernandes@gmail.com (M.E.F.)

2 RRodio-RRodio Consultoria ,São Paulo 01311-902, Brazil; rodguerra2@gmail.com

3 UNICAMP_College of Technology, State University of Campinas, Limeira 13484-332, Brazil; h190839@dac.unicamp.br

* Correspondence: marcelo.okano@cps.sp.gov.br; Tel.: +55-119-9109-6575

check for

updates

Citation: Gomes, J.G.C.; Okano, M.T.; Guerra, R.S.; Cordeiro, D.d.S.; Santos, H.C.L.d.; Fernandes, M.E. Analysis of Sustainable Business Models:

Exploratory Study in Two Brazilian Logistics Companies. Sustainability 2022, 14, 694. https://

doi.org/10.3390/su14020694

Academic Editors: Paulo Afonso,

Antonio Zanin and Orlando Durán

Received: 7 December 2021

Accepted: 6 January 2022

Published: 9 January 2022

Publisher's Note: MDPI stays neutral with regard to jurisdictional claims in published maps and institutional affiliations.

Copyright: () 2022 by the authors Licensee MDPI, Basel, Switzerland. This article is an open access article distributed under the terms and conditions of the Creative Commons Attribution (CC BY) license (https:// creativecommons.org/licenses/by/ $4.0 /)$.

\begin{abstract}
Over the years, researchers have presented different concepts regarding business models. There is no unanimity, but there is a general agreement that a business model is the representation of how a company conducts its business. Subsequently, interest in the topic has increased and has come to be considered by companies that, driven to incorporate a positive contribution to sustainability into their values, began to face economic development that considers social and environmental aspects instead of worrying only about profit for the shareholders. The general objective of this research is to identify how the merger of two Brazilian logistics companies with different customer segments can positively contribute to the defense of sustainability, considering social and environmental aspects. As a methodology, a literature review on business models, conceptual business models, and sustainable business models was used to legitimize issues relevant to the themes. The case studies allowed for a measurement of the productivity of the areas of the chosen companies, and a survey of used business processes and technological systems, in addition to diagnosing the level of maturity of these areas. An analysis of the strengths and weaknesses in these areas, within the studied companies, resulted in a solution that allowed for the optimization of processes and savings in human and material resources, and the identification of qualitative benefits arising from mergers, improvements in productivity and services, the standardization of processes, and the implementation of innovative digital technologies.
\end{abstract}

Keywords: business models; sustainable business models; merger of companies; logistics; sustainable economy

\section{Introduction}

The complexity and dynamism of modern business environments have led to companies needing powerful tools that translate relevant aspects into an embracing solution. Traditional business models were effective in their many application areas, but they sometimes failed to provide the comprehensive solution needed to integrate and examine different, complex, and often changing conditions [1]. Business complexity continues to grow, with new business models, channels, competitors, and customer needs that drive performance expectations. This complexity is visible both in the variety of use cases that require an analytic view, and in the speed and relevance of how analytics teams must deliver those insights [2].

There is no unanimity, but there is an agreement that a business model is the representation of how a company conducts its business. Interest in the topic has expanded and become part of the agenda of companies that, driven to incorporate a positive contribution to sustainability into their values, have begun to face economic development that considers social and environmental aspects, and not just profit to shareholders. 
In addition to requirements for satisfactory economic performance, organizations are responsible for the positive socioenvironmental performance of their operations and, indirectly, for the activities of their partners and suppliers [3].

The importance of environmental and social aspects can be seen through the defense of sustainability, the Brazilian commitment to fulfilling the Sustainable Development Goals established by the United Nations (UN), and the recent commitment at the summit of leaders on climate.

Supply chain management and the incorporation of sustainability into management are measures that have been adopted by different organizations and market segments of which the objectives are competitive differentiation and the achievement of long-term development in the market [4].

Given this scenario, the research question is "how can the merger of two Brazilian logistics companies contribute positively to the defense of sustainability?", and the general objective is to identify how the merger of two Brazilian logistics companies with different customer segments can positively contribute to the defense of sustainability, considering social and environmental aspects from the perspective of business models.

A bibliographical review on "business models", "conceptual business models", "sustainable business models", "logistics", "supply chains", "sustainable supply chains", and "innovation in sustainable management" was used to legitimize pertinent questions about the themes, allowing for the choice of the theoretical lens of Osterwalder et al. [5,6] regarding business models, and the sustainable business models of Bocken et al. [7] as sources of external evidence. As a source of internal evidence, surveys were carried out with employees and managers of the procurement, accounts payable, accounts receivable, treasury, invoicing and billing, accounting, tax, human resources, information technology, and fleet management departments of two logistics companies in a mergers and acquisitions (M\&A) process. These areas were chosen because they presented a duplication of activities, impacting the organization and productivity of back office operational services.

This research considered mergers and acquisitions (M\&A) as sustainable innovation, considering that a merger occurs when two or more companies decide to pool their resources under a common entity, and an acquisition occurs when a company exercises effective control over the assets or management of another company without merging their businesses [8].

The great innovation potential of this research is to analyze the relationship between the theory of sustainable business models and business practice in the logistics sector [9].

\section{Literature Review}

In the literature review, we clarified theoretical assumptions that supported the research and the contributions that the research offered [10]. "Business models", "conceptual business models", "sustainable business models", "logistics, supply chain, and sustainable supply chain", and "innovation in sustainable management" were used to legitimize the pertinent questions about the themes, allowing the choice of the theoretical lens of Osterwalder and Pigneur [5,6] on business models and the sustainable business models of Bocken et al. [7] as sources of external evidence.

\subsection{Business Models}

In the context of the business model, the "model" is the abstract representation of how an organization's business activities work, and "business" can be understood as the structured transformation of input factors into products and services [11,12]. A business model provides a simplified representation of value-creation processes, roles, and interactions to create customer value by ensuring competitive advantage and generating revenue, using a comprehensive aggregated picture of reality that can integrate political, legal, economic, sociocultural, technological, and ecological aspects into the transparent architecture to manage complexity $[1,12]$. 
According to Dolesky [1], the complexity and dynamism of modern business environments have led to companies needing powerful tools that translate all relevant aspects into a comprehensive solution. Old business models do not offer the broad solutions needed for so many different, complex, and changing environments [1]. Business complexity continues to grow with new business models, channels, competitors, and customer needs that drive performance expectations. These areas require excellence and innovation in planning and execution across all business functions. This complexity is visible both in the variety of use cases that require an analytic view, and in the speed and relevance of how analytics teams must deliver those insights [2].

\subsection{Conceptual Model}

A business model is defined by three main elements: value proposition, value creation and delivery, and value capture. Creating value is at the heart of any business model. Companies often capture value by taking advantage of new business opportunities, markets, and revenue streams [13-15].

A business model is projected through the perception of customers with unsatisfied (or unmet) needs. Successful projection provides a product or service to the customer who is willing to pay more for that product or service [16]. The customer thus covers all costs and generates enough profit to sustain the business and its growth [17].

The conceptual approach to business models is presented in different ways in the literature. However, three main value-based elements can be distinguished: value proposition, value creation and delivery, and value capture [18].

The conceptual model describes the value that a company provides to customers and its partner network to create, sell, and deliver that value to generate profitable revenue streams $[5,6]$.

Table 1 presents the construction of the business model blocks.

Table 1. Nine business model building blocks.

\begin{tabular}{|c|c|c|}
\hline Pillar & $\begin{array}{l}\text { Business Model } \\
\text { Building Block }\end{array}$ & Description \\
\hline Product & Value proposition & $\begin{array}{c}\text { Overview of a company's package of products } \\
\text { and services }[5,6] \text {. }\end{array}$ \\
\hline \multirow{3}{*}{ Customer interface } & Customer segment & $\begin{array}{l}\text { Describes customer segments to which a } \\
\text { company wants to provide value }[5,6] \text {. }\end{array}$ \\
\hline & $\begin{array}{l}\text { Relationship with } \\
\text { customers }\end{array}$ & $\begin{array}{c}\text { Explains types of links that a company } \\
\text { establishes between itself and its different } \\
\text { customer segments }[5,6] \text {. }\end{array}$ \\
\hline & Distribution channel & $\begin{array}{c}\text { Describes the company's various ways to contact } \\
\text { its customers }[5,6] .\end{array}$ \\
\hline \multirow{3}{*}{$\begin{array}{l}\text { Infrastructure } \\
\text { management }\end{array}$} & Key resources & $\begin{array}{c}\text { Describes the arrangement of activities and } \\
\text { resources }[5,6] .\end{array}$ \\
\hline & Key activities & $\begin{array}{l}\text { Describes needed competencies to run the } \\
\text { company's business model }[5,6] \text {. }\end{array}$ \\
\hline & Key partners & $\begin{array}{c}\text { Depicts the network of cooperation agreements } \\
\text { with other companies to offer and commercialize } \\
\text { with value efficiency }[5,6] .\end{array}$ \\
\hline \multirow{2}{*}{ Financial Aspects } & Cost structure & $\begin{array}{l}\text { Summarizes monetary consequences of } \\
\text { employed means in the business model }[5,6] \text {. }\end{array}$ \\
\hline & Revenue stream & $\begin{array}{c}\text { Describes how a company earns money through } \\
\text { various revenue streams }[5,6] .\end{array}$ \\
\hline
\end{tabular}

Source: Based on Osterwalder and Pigneur [5,6] 
According to Alegre and Berbegal-Mirabent [19], business models provide a consistent and integrated picture of a company, describing the rationale for how an organization creates, delivers, and assesses value captures, and identifying the elements and relationships that describe how the business operates.

\subsection{Sustainable Business Models}

According to Bocken et al. [20], sustainable business models incorporate in their financial considerations the interests of the involved parties, including those concerning the environment and society, thus differentiating themselves from the concept of the business model, which only considers the cost structure and the revenue stream in its financial considerations.

Due to the growth of academic and business interest in sustainable business models, Geissdoerfer et al. [21] conducted a literature review on the topic. According to the authors' definitions, sustainable business models are a modification of the conventional business model concept that incorporates concepts, principles, or goals that aim to integrate sustainability into its value proposition, value creation, and delivery activities, and/or value-capture mechanisms [21].

One of the differences between conventional and sustainable business models [22] is that sustainable business models allow for a holistic view of how business is conducted, considering the interests of shareholders and environmental and social sustainability metrics [22,23]. According to Bocken et al. [20], their importance also lies in driving and implementing corporate innovation for sustainability, helping it to be incorporated into both corporate purposes and business processes, contributing to the achievement of a competitive advantage.

Due to the growing concerns about sustainability summarized in the UN's Sustainable Development Goals, sustainable business models are of interest to researchers and companies [7,23]. Adopted by all UN member states in 2015, the Sustainable Development Goals provide that all countries should promote prosperity while protecting the environment, social needs, equality, and employment opportunity, combating climate change and preserving nature $[7,23]$. Thus, sustainable business models incorporate the creation of monetary and nonmonetary value into this framework for a wide range of stakeholders from a long-term perspective [21,22].

Sustainable business models are very helpful to Industry 4.0, which can be conceptualized as a new stage of industrial maturity for product firms, based on the connectivity provided by the industrial Internet of Things, where the products and processes of companies are interconnected and integrated to obtain greater value for customers and internal company processes [24].

Industry 4.0 is increasingly being explored by academics, researchers, practitioners, and other relevant stakeholders. The idea of Industry 4.0 is supported by the advancement of information and communication technologies (ICTs) and data storage [25].

Industry 4.0 offers potential for new and innovative business models. However, established manufacturing firms tend to be more oriented towards improving the efficiency of their processes through Industry 4.0 [26].

Müller et al. [27] consider that the business model concept thereby generates an understanding of how organizations can use Industry 4.0 to provide value offerings and appropriate pricing models to their customers.

The technical innovations associated with Industry 4.0 offer the possibility to adapt existing business models or develop new ones. Furthermore, other companies can enter the market and influence the value chain. For business models to adapt, data must be stored in such a way that suppliers and manufacturers are functionally integrated into the value chain [28].

Another important point for the sustainable business model is the environmental issue. Therefore, it seems logical that environmental thinking should be included in the business model and that it should be the object of business model innovation [29]. 
From the literature, the authors identified that the primary objective of establishing a sustainable business model is environmental issues, but achieving economic performance and gaining market share increase competition among companies. The authors also identified that increasing financial performance results in the development of a competitive business model [30].

\subsection{Business Model Canvas and Sustainable Business Model}

Osterwalder [31] developed a doctoral thesis in 2004 titled The Business Model Ontology-the Proposition in a Design Science Approach, under the supervision of Yves Pigneur; the objective was to approach the concept of business models ontologically to provide the basis for new management tools. Based on their thesis, Osterwalder and Pigneur [6] launched the book Business Model Generation, presenting the Business Model Canvas for the first time; according to Burkett [32], it offers a simple, visual, and one-page canvas on which it is possible to design, innovate, and discuss business models.

For Osterwalder and Pigneur [6], the business model represents parts of the planned strategy to be implemented within their organizational structures, processes, and interdependent systems.

Osterwalder [12,31] developed a study evaluating and comparing the most common construction models in the literature, and on that basis identified the most frequently mentioned components. The result of this research consisted of a synthesis with nine building blocks, covering all components of the business models mentioned by at least two authors, excluding elements related to competitors.

The aim of the authors in developing the business model canvas was to allow anyone interested to create or modify a business model, since its screen has a clear language, allowing for the exchange of ideas among those involved in the business modeling process [33].

Figure 1 shows the interaction among business model canvas blocks.

\begin{tabular}{|c|c|c|c|c|}
\hline \multirow[t]{2}{*}{$\begin{array}{c}\text { Key partners } \\
\text { main network of } \\
\text { suppliers and partners } \\
\text { that make the business } \\
\text { model work }\end{array}$} & $\begin{array}{l}\text { Key activities } \\
\text { ability to perform the most } \\
\text { important necessary } \\
\text { actions to create value for } \\
\text { customers }\end{array}$ & \multirow{2}{*}{$\begin{array}{c}\text { Value } \\
\text { proposition } \\
\text { set of products and } \\
\text { services that create } \\
\text { value for a specific } \\
\text { customer segment }\end{array}$} & $\begin{array}{c}\text { Customer } \\
\text { relationship } \\
\text { types of relationships } \\
\text { established between } \\
\text { customers }\end{array}$ & \multirow[t]{2}{*}{$\begin{array}{l}\text { Customer segment } \\
\text { Different groups of } \\
\text { people to whom you } \\
\text { want to offer something } \\
\text { of value }\end{array}$} \\
\hline & $\begin{array}{l}\text { Key resources } \\
\text { organizing the } \\
\text { activities and resources } \\
\text { needed to create value } \\
\text { for customers }\end{array}$ & & $\begin{array}{l}\text { Channels } \\
\text { means employed to } \\
\text { keep in contact with } \\
\text { customers }\end{array}$ & \\
\hline \multicolumn{2}{|c|}{$\begin{array}{c}\text { Cost structure } \\
\text { all costs involved in operating the } \\
\text { business model }\end{array}$} & \multicolumn{2}{|c|}{$\begin{array}{l}\text { how the company makes money } \\
\text { in each customer segment }\end{array}$} & \\
\hline
\end{tabular}

Figure 1. Business model canvas blocks. Source: Based on Osterwalder and Pigneur [6].

According to Figure 1, five blocks of the business model refer to the external aspects, namely, value proposition, customer relationship, customer segment, channels, and revenue stream, while the others refer to the internal aspects: key activities, key partners, key resources, and cost structure. Bocken [7] considers that the first groupings of the bestknown sustainable business models were oriented towards the combination of products and services such as leasing and renting. To expand this list and capture emerging practices in the field, archetypes of sustainable business models were developed and classified according to more technological, social, and organizational types [20]. 
To illustrate sustainable business models, different elaborations have emerged in recent years, such as the flourishing screen by Jones and Upward in 2014, and the screen of the sustainable business model [34]. Figure 2 illustrates an example of this screen from the sustainable canvas business model.

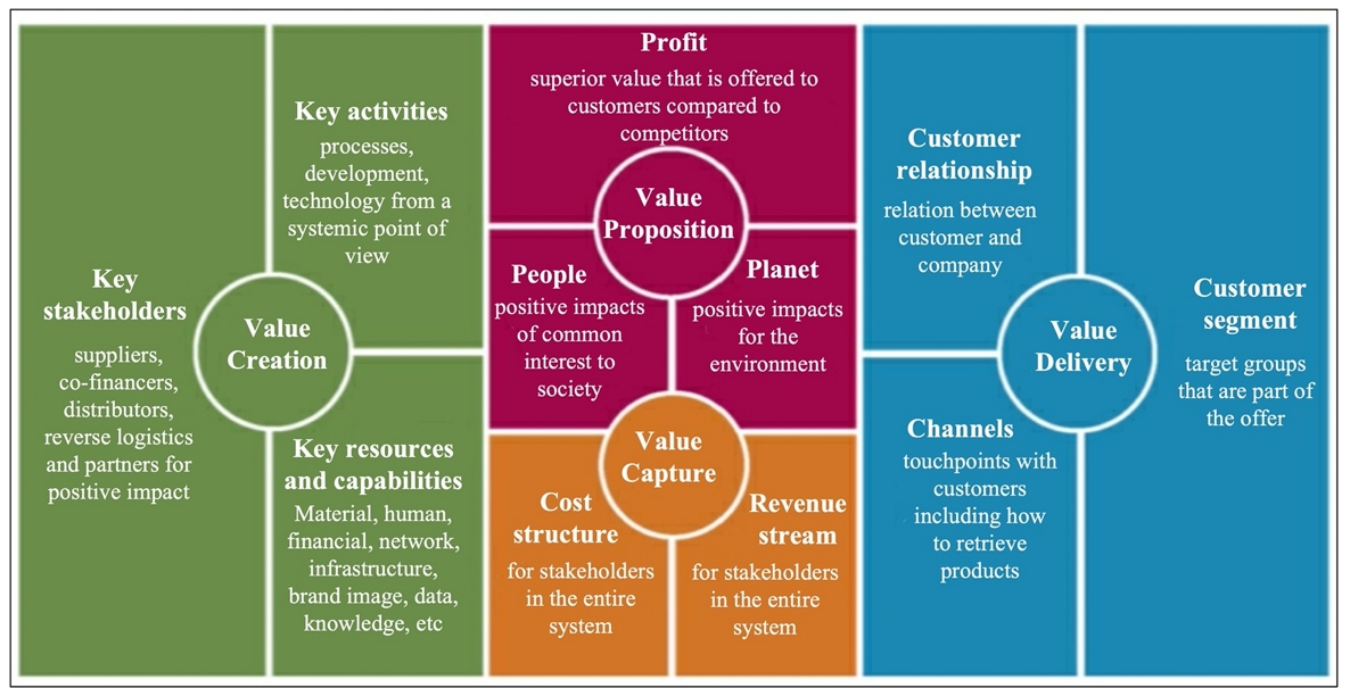

Figure 2. Screen of sustainable business model canvas. Source: based on Bocken et al. [34], Osterwalder and Pigneur [6], and Richardson [35].

According to Figure 2, three archetypes are incorporated into the conceptual business model of Osterwalder and Pigneur [6]. Thus, in the value proposition structure, the elements of profit, people, and planet appear, categorizing the holistic approach necessary to face the challenges of a sustainable future, focusing on environmental changes in parallel with economic and social changes [20].

Sustainable business models use the triple base (people, profit, and planet) to measure the performance of companies, in addition to promoting environmental management in a systemic way, significantly impacting business growth prospects [7].

Interest in the topic has expanded and is part of the agenda of companies, which, driven to incorporate within their values a positive contribution to sustainability, have begun to seek not only profit for their shareholders, but to face the challenges of development, considering social and environmental aspects.

The Sustainable Development Goals illustrated by the UN and faced by companies and by society in Brazil and globally are [37]: (1) No poverty; (2) Zero hunger; (3) Good health and well-being; (4) Quality education; (5) Gender equality; (6) Clean water and sanitation; (7) Affordable and clean energy; (8) Decent work and economic growth; (9) Industry, Innovation, and Infrastructure; (10) Reduced inequality; (11) Sustainable cities and communities; (12) Responsible consumption and production; (13) Climate action; (14) Life below water; (15) Life on land; (16) Peace, justice and strong institutions and (17) Partnership for the goals.

Sustainable Development Goals drive global actions to eradicate poverty and protect the environment and the climate, guaranteeing people everywhere the possibility of enjoying peace and prosperity [37]. Launched in 2015, the 2030 Agenda is the joint work of governments, companies, and citizens towards the creation of a new sustainable global socioenvironmental model.

\subsection{Logistics, Supply Chain, and Sustainable Supply Chain}

In today's business world, it is very difficult for a company to become competitive without the collaboration of external partners. The concept of supply chain management emerged in this direction and seeks to better manage the physical and changed information 
flow among all supply chain participants whose objective is to achieve simultaneous cost reduction through the supply chain and increase the value of goods and/or services [38].

According to Arredondo and Tanco [36], the origin of supply chain management (SCM) mainly depends on logistical reality. This is how SCM and logistics are strongly connected, although they are not identical. Strategic vision, internal integration, and relationships that transcend company boundaries represent an integral part of SCM. Figure 3 shows this evolution.

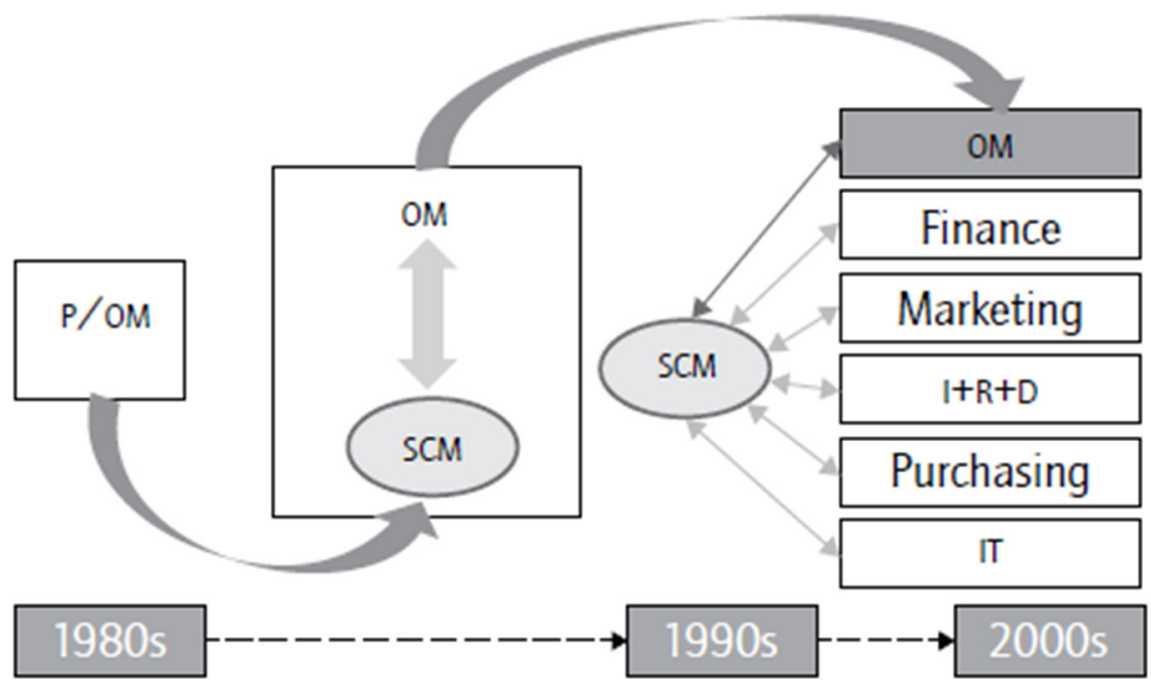

Figure 3. SCM evolution. Source: Based on Arredondo and Tanco [36].

According to Copacino [39], supply chain management or logistics refers to the art of managing the flow of materials and products from origin to user. Ballou [40] believes that integrated logistics management is strengthened in the rationalization of operating costs, improving services and changing the environment, promoting global logistics and organizational strategic growth.

Organizational disputes occur at various operational levels, such as innovative products and processes and reducing operating costs and investments, in addition to increasing customer expectations. In this case, the logistical process that alternates between a completely vertical position and partnerships with several professional suppliers stands out [41].

Bowersox and Closs [42] highlighted that the movement of materials is not limited to moving, boxing, and storage, but extends to the performance of these functions, considering the available time and space. Production support activities should not be stand-alone procedures, but should be integrated into the activity system to maximize the total productivity of the facility or warehouse.

In this scenario, according to Aguezzoul [38], logistics companies can be highlighted, as they have benefited widely from the phenomenon of outsourcing, accelerating their growth. This growth is mainly attributed to benefits related to cost reduction, performance improvement, a focus on the core business, and the construction of virtual ventures through strategic alliances. Table 2 presents activities associated with contract logistics.

Even though the chain structure and business processes remain in their traditional form, the dynamics of how organizations pursue integration across supply chains has changed. In addition to requirements for satisfactory economic performance, organizations are now responsible for the positive socioenvironmental performance of their operations and, indirectly, of the activities of their partners and suppliers [3]. 
Table 2. Associated activities with contract logistics.

\begin{tabular}{cc}
\hline Logistics Processes & Activities \\
\hline Transportation & $\begin{array}{c}\text { Transportation by road, rail, air, or sea, intermodality management, } \\
\text { shipping, forwarding, package express carrier, customs brokering, (de) } \\
\text { consolidation, perishable/hazardous goods management, freight bill } \\
\text { payment/audit. }\end{array}$ \\
\hline $\begin{array}{c}\text { Outbound } \\
\text { (Distribution) }\end{array}$ & $\begin{array}{c}\text { Merge in transit, order fulfilment/processing, picking, sorting, } \\
\text { dispatching, post-production configuration, installation of products at } \\
\text { the customer's site. }\end{array}$ \\
\hline Warehousing & $\begin{array}{c}\text { Storage, receiving, cross-docking, (de)consolidation, } \\
\text { perishable/hazardous goods. }\end{array}$ \\
\hline Inventory & $\begin{array}{c}\text { Forecasting, slotting/lay out design, location analysis, } \\
\text { storage/retrieval management }\end{array}$ \\
\hline Packaging & Design, labeling, assembly/packaging, palletizing \\
\hline Reverse logistics & $\begin{array}{r}\text { Pallet-flow management, recycling, reuse, remanufacturing disposal } \\
\text { management, repair, testing/product serving, return } \\
\text { shipment management. }\end{array}$ \\
\hline Source: Based on Aguezzoul [38].
\end{tabular}

Source: Based on Aguezzoul [38].

The standout factor is sustainable supply chain management (SSCM) or green supply chain management (GSCM), which has received much attention due to the increased awareness of climate change and global environmental and social issues [43]. GSCM can be defined as the coordination of the supply chain to integrate environmental concerns and consider interorganizational activities [44].

For the past two decades, SSCM has focused on integrating environmental, social and economic objectives into all the supply chain processes of large companies [45,46]. Herrmann et al. [47], reported that, in recent years, around $70 \%$ of the leading companies in any given sector emphasized sustainable development in their work programs. Reports from leading companies confirm that the success of sustainability efforts also depends on collaboration between supply chain actors $[48,49]$.

Green supply chain management ensures the effectiveness of public and corporate policies to make their operations cleaner, increasing market share and profits and improving their images and reputations [47].

The SSCM aims to integrate the triple-baseline (TBL) premise in the development of adequate strategies for supply chain management [3].

The formal definition of TBL in sustainability includes environmental, social, and economic dimensions, indicating that traditional performance measurement based on economic profit should be extended to include the environment and people's wellbeing [50,51].

Pagell and $\mathrm{Wu}$ [52] explain the introduction of sustainability practices in the supply chain and indicate that a company can be proactive and committed only when the business model is consistent with the environmental and social elements of sustainability.

\subsection{Innovation in Sustainable Management}

According to Rocha et al. [4], sustainable management is premised on incorporating economic, social, and environmental factors into an organization's strategy and operations, making it a new challenge for companies.

This challenge becomes greater as a company seeks to obtain a competitive advantage and simultaneously considers the social and environmental impacts associated with its productive activities, as well as the adoption of sustainable management that incorporates economic, social, and environmental factors into its strategies and organizational operations. Sustainable management must exist in the composition of the entire production chain of industrial activities. Therefore, the sustainability strategy must range from suppliers of raw materials and other supplies to final consumers [53]. 
To understand how to implement sustainability in supply chains, it is first necessary to understand its general dynamics. The supply chain is not in fact a linear chain, but is a complex network with many connections among different participants. The globalization process has strengthened this feature, and the relationship between different participants is extremely complex and diverse [53].

The management of the supply chain and the incorporation of sustainability into management are measures that have been adopted by different organizations and different market segments, whose objective is competitive differentiation and the reach of long-term development in the markets [4]. Some authors define supply chain management and the incorporation of sustainability as a sustainable supply chain, as already presented in Section 2.5.

In recent decades, compared to traditional models that focus on economic returns, the literature has emphasized the importance of incorporating the concept of sustainability into a company's business model [54]. For Jabłoński [55], it is very likely that the future starting points for achieving a sustainable market advantage are the right business model, location in the market, and a continuous hierarchical organization. The growing importance of business models is a result of the combination of information and communication technologies, the deregulation of markets, technological changes, globalization, the role of sustainable development, and the growth of corporate social responsibility.

Business model innovation has recently increased in academic research and business practice. Changes in business models are the basic method for achieving sustainable innovation. However, little is known about the successful adoption of sustainable business models (SBMs) [56]. The SBM concept focuses on creating ecological, social, and economic value for key companies [57].

Sustainable innovation can be defined as the introduction of novelties or modifications in production processes, techniques, systems, organizations, and products to reduce environmental damage [58].

González-Torres et al. [59] considered that the traditional financial theory has the sole mission of maximizing shareholder value. However, companies are currently under strong pressure to improve their corporate social performance (CSP) and integrate sustainability into their business practices. In previous research and practice, most theories and ideas used to assess the effectiveness of mergers and acquisitions are rooted in the old competitive environment previously dominated by manufacturing. In high-tech mergers and acquisitions, the integration of technological capabilities is the best indicator of business synergy, as opposed to evaluating the relationship between the market and the product portfolio [60].

This research considered mergers and acquisitions (M\&A) as sustainable innovation, considering that a merger occurs when two or more companies decide to pool their resources under a common entity, and that acquisition occurs when a company exercises effective control over the assets or management of another company without merging their businesses [8].

Mergers and acquisitions can alter activities that span the entire supply chain, including sourcing, manufacturing, distributing, and delivering materials. Supply chain management under mergers and acquisitions continues to be widely studied as a source of operational coordination [61]. In fact, improving supply chain performance represents the greatest cost-saving advantage, especially in the context of horizontal consolidation [62-64].

\section{Methods}

Descriptive exploratory research was chosen, as it aims to provide greater familiarity with the problem to make it more explicit, and descriptive research aims to describe the characteristics of a given population or phenomenon [10].

For Yin [65], the case study is: "An empirical investigation that investigates contemporary phenomena in the context of real life, when the boundary between the phenomenon and the context is not clear". In relation to the research questions, the case studies try to 
answer the "how" and "why" phenomena; they don't need to control behavioral events; and still focus on contemporary events [65].

Through a descriptive exploratory case study, it was possible to analyze the new sustainable business model that had been created by the merger of the two companies while simultaneously identifying some of the 17 Sustainable Development Goals stipulated by the UN for the 2030 agenda.

For reasons of confidentiality, the acquiring company was named A, and the acquired company was named B; their characteristics are described below:

Company A:

Company A began its activities with a focus on the business-to-consumer (B2C) segment and showed sustainable growth in recent years. Initially, the customer segment was focused on e-commerce services; over the years, however, it expanded into different segments. Currently, in addition to e-commerce, the company provides services to the payment-method delivery market, being responsible for its integrated logistics. The operational process ranges from storage, installation, exchange, and maintenance to reverse logistics. The company performs fast deliveries and offers dedicated operations for deliveries of between 4 and $6 \mathrm{~h}$ after the customer's order. One of the market expansion strategies is acquisitions. Over the past few years, the company has acquired several companies operating in its field, expanding its presence in the market. Its strategy is to incorporate the knowledge of its competitors, expanding its operations horizontally (competing companies) and vertically (complementary companies) without having to start from scratch.

It appears that company A has programs aimed at environmental, social, and economic issues and addresses the context of sustainability in its mission, vision, and values. It has approximately 13,000 employees at facilities located in the southern and southeastern states of Brazil, and its headquarters are in the metropolitan region of greater São Paulo. It has ISO 9000 and 14,000 certifications.

Company B:

Acquired in 2020, being one of the pioneers in the country's cargo transport sector, Company B operates in the business-to-business (B2B) segment of road transport services and fractional cargo for the pharmaceutical, cosmetics, e-commerce, electronics, auto parts, textile, clothing, and footwear segments. Through integration with other divisions of the company, the express unit offers logistic solutions, customized projects, and road and air transport. It has about 3000 employees and is one of the largest logistics operators on the national scene with a focus on fractional transport.

Company B also has programs focused on environmental, social, and economic issues and addresses the context of sustainability in its mission, vision, and values. Its operation and headquarters are in the metropolitan region of Campinas. It has ISO 9000 and 14,000 certifications.

The steps of the methodological procedure were:

1. The sources of evidence for the case study: As a source of internal evidence, interviews were carried out with managers in the areas of two Brazilian logistics companies in the mergers and acquisitions process. As external evidence, we used secondary sources such as company websites, minutes, and reports of internal meetings, documents, and observations. Both the internal and external evidence sources guaranteed the routines for the triangulation and constituted the basis for the validation of the qualitative research. For Yin [65], triangulation is a rationale for using various sources of evidence, allowing both the development of converging lines of investigation and the data obtained considering its analysis to become more accurate and convincing.

2. Instruments and protocols: The protocol provided a series of open and semi-structured questions to guide general discussions. It was based on the conceptual models of the Business Model Canvas and the Sustainable Business Model. The research instrument was a semi-structured script with open and closed questions specific to each area according to the activities described. Respondents were asked to provide data to measure the productivity of their administrative routines, characterizing the current 
scenario (as is). The interview was the main source of data collection that was carried out with the managers of each area of the two companies.

3. Data collection: Data collection was carried out through semi-structured interviews with managers from each area of the two companies. The interviews were scheduled, allowing them to take place in an appropriate place, avoiding the intervention of other people or routine activities. The interview allowed the researcher to ask the key respondent about facts, or ask for their opinion about certain events [65]. The interviews were recorded and transcribed. Each set of interviews and materials was synthesized according to common protocol categories and developed as a detailed case study for each area, following a common format, systematically exploring the same facets of each company in turn. Managers from the following areas were interviewed: procurement, accounts payable, accounts receivable, treasury, invoicing/billing, accounting, tax, human resources, information technology, and fleet management

4. Data analysis: The collected data were compared with the theories studied, selecting the best practices in each area and planning and building new scenarios for the companies (to be). The interviews were carried out to verify whether the concepts studied in the literature review were equivalent to the tacit knowledge of the interviewees Analysis strategy was the narrative strategy, which aims to provide stories, meanings, and mechanisms [66]. Fenton and Langley [67] elucidate that the narrative mode of analysis focuses on the elements that constitute the narrative, such as its sequence, its plot, and its characters present in the conversation, as well as documents and organizational texts. The authors seek to clarify how the perspective can be rich in practical analysis and, finally, strategic texts. The analytical results allowed for the measurement of the productivity of the chosen areas of each of the companies, and a survey of the business processes and technical systems used, in addition to diagnosing the level of maturity of these areas. To measure productivity, the managers of each area were essentially asked to assign weights to each process according to its importance and criticality and then, for each human resource, they gave grades from 0 to 10 according to efficiency, time with the company, and importance. To calculate productivity, a weighted average of processes and human resources was made. To obtain the grades and weights of each process by area, interviews were conducted using a closed script with the managers of each area of each of the companies. This data was analyzed, and productivity indicators were generated.

5. Data discussion and conclusion: The case study resulted in a restructuring of the areas, consideration of the optimization of processes, identification of the qualitative benefits resulting from the merger, improvements in productivity and service, the standardization of processes, and the implementation of innovative digital technologies. Thus, with a new operational and technological model, the acquiring company was able to focus on a sustainable growth platform with greater focus on business activities and gains in quality and productivity in internal and external services.

\section{Analysis and Results}

The internal analysis of the merger of companies was carried out using the Canvas business model. Subsequently, the results were applied to the Canvas sustainable business model, identifying the social and environmental aspects.

Using the case study, it was possible to prepare the canvas of the sustainable business model, contemplating the merger of companies and considering the main areas involved and impacted, as well as the standardization of business processes and the implementation of innovative digital technologies.

Subsequently, it was possible to analyze in detail the organizational model of the acquiring company after the merger. 


\subsection{Value Proposition}

Profit: A quality standard present in all stages of each logistics project, from the packaging of goods and preparation for distribution at the points of sale to the delivery of products at the destination, allows for better prices for services. The increase in profits is also due to the creation of a competitive advantage, since the customers' product inventories are stored in the company's warehouses, accelerating the flow and directly impacting the delivery time, which can often be up to a day shorter than expected.

This creation of a competitive advantage is congruent with Jabłoński's [55] analysis, which assumes that the future starting points for achieving a sustainable market advantage are the right business model, location in the market, and continuous hierarchical organization.

For the merger process, the productivity structure of areas that presented activity duplication was analyzed, resulting in new adjusted productivity for the chosen areas of Companies $\mathrm{A}$ and $\mathrm{B}$.

Table 3 shows the adjusted productivity of Companies A and B.

Table 3. Adjusted productivity of Companies A and B.

\begin{tabular}{|c|c|c|c|c|c|}
\hline Area & Activities & $\begin{array}{c}\text { Initial } \\
\text { Productivity } \\
\text { Company A }\end{array}$ & $\begin{array}{c}\text { Initial } \\
\text { Productivity } \\
\text { Company B }\end{array}$ & $\begin{array}{c}\text { Company A } \\
\text { Adjusted } \\
\text { Productivity }\end{array}$ & $\begin{array}{c}\text { Company B } \\
\text { Adjusted } \\
\text { Productivity }\end{array}$ \\
\hline Procurement & Quantity of procurement/month & 96 & 125 & 115 & 150 \\
\hline Accounts payable & Amount of bills paid/month & 2604 & 1777 & 3125 & 2132 \\
\hline Accounts receivable & Amount of receipts/month & 2245 & 3026 & 2694 & 3631 \\
\hline Treasury & Amount of bank reconciliation & 56 & 16 & 67 & 19 \\
\hline Invoicing/billing & $\begin{array}{l}\text { Quantity of registrations made } \\
\text { (customers)/month }\end{array}$ & 224 & 63 & 291 & 76 \\
\hline Accounting & $\begin{array}{l}\text { Number of companies for } \\
\text { accounting closing }\end{array}$ & 1 & 0.3 & 1 & 0.4 \\
\hline Tax & $\begin{array}{l}\text { Quantity of branches for } \\
\text { tax obligations }\end{array}$ & 6 & 7 & 7 & 8 \\
\hline Human resources & Number of company employees & 687 & 687 & 790 & 824 \\
\hline Information technology & Number of infrastructure calls & 99 & 25 & 119 & 29 \\
\hline Fleet management & Quantity of fleet vehicles & 305 & 102 & 366 & 117 \\
\hline
\end{tabular}

To calculate adjusted productivity, the activities performed by each area, the monthly volume of each activity, and the number of employees per performed activity were considered.

Under the initial productivity, a process compression lever was inserted, chosen from three scenarios: conservative, moderate, and aggressive, with compressions of 15\%, 20\%, and $30 \%$. respectively. The percentages come from knowledge management acquired over the years, through the experiences of the specialists involved in the merger project.

To choose the best scenario for each area of the two companies, all processes were mapped and redesigned, considering the best organizational practices, optimizing activities by reducing gaps, and developing opportunities for improvement. For this purpose, the managers of each area involved were interviewed and the future processes designed together with the responsible technical area. After the calculations of adjusted productivity, centralized productivity was calculated.

For the calculation of centralized productivity, a process centralization lever was created and applied to the best of the adjusted productivities of the two companies, considering the choice of three possible scenarios: conservative, moderate, and aggressive, with compressions of $3 \%, 6 \%$, and $10 \%$, respectively. Like the process compression lever, the percentages come from knowledge management acquired over the years, through the experiences of the specialists involved in the merger project. 
Table 4 shows the projection of the centralized productivity of the duplicated activities.

Table 4. Projection of centralized productivity of duplicated activities.

\begin{tabular}{|c|c|c|c|c|c|}
\hline Area & Activities & $\begin{array}{l}\text { Company A } \\
\text { Adjusted } \\
\text { Productivity }\end{array}$ & $\begin{array}{l}\text { Company B } \\
\text { Adjusted } \\
\text { Productivity }\end{array}$ & $\begin{array}{c}\text { Centralized } \\
\text { Productivity } \\
\text { Companies A And B }\end{array}$ & $\begin{array}{c}\text { Growth } \\
\text { Centralization } \\
\text { Productivity }\end{array}$ \\
\hline procurement & $\begin{array}{c}\text { quantity of } \\
\text { procurement/month }\end{array}$ & 115 & 150 & 155 & $3 \%$ \\
\hline accounts payable & amount of bills paid/month & 3125 & 2132 & 3437 & $10 \%$ \\
\hline accounts receivable & amount of receipts/month & 2694 & 3631 & 3994 & $10 \%$ \\
\hline treasury & amount of bank reconciliation & 67 & 19 & 74 & $10 \%$ \\
\hline invoicing/billing & $\begin{array}{l}\text { qty of registrations made } \\
\text { (customers)/month }\end{array}$ & 291 & 76 & 320 & $10 \%$ \\
\hline accounting & $\begin{array}{l}\text { number of companies for } \\
\text { accounting closing }\end{array}$ & 1 & 0 & 1 & $10 \%$ \\
\hline $\operatorname{tax}$ & $\begin{array}{l}\text { qty of branches for } \\
\text { tax obligations }\end{array}$ & 7 & 8 & 9 & $10 \%$ \\
\hline human resources & $\begin{array}{c}\text { number of } \\
\text { company employees }\end{array}$ & 790 & 824 & 849 & $3 \%$ \\
\hline $\begin{array}{l}\text { information } \\
\text { technology }\end{array}$ & number of infrastructure calls & 119 & 29 & 122 & $3 \%$ \\
\hline fleet management & quantity of fleet vehicles & 366 & 117 & 388 & $6 \%$ \\
\hline
\end{tabular}

The projection of the centralized productivity of Companies A and B allowed for the areas that previously worked in isolation to integrate, offering fluidity and optimization of the execution time of activities.

After centralization and unification, centralized productivity experienced an average growth of $8 \%$, considering duplicated activities.

This better management of the supply chain allowed for an average of $8 \%$ growth in centralized productivity, considering duplicated activities. In this way, according to Aguezzoul [38], supply chain management seeks to better manage the physical and changed information flow among all participants, whose objective is to simultaneously achieve cost reduction and value increase in goods and/or services.

People: implementation of the best process maturities in the chosen areas of each of the companies, identifying possibilities for improvement in employee training and qualification. To prepare the maturity diagnosis, the main processes in each area were subdivided into subprocesses, and a list of criteria were developed to identify the structure of internal routines.

Internal routines were analyzed to identify their stage (initial, repetitive, defined, managed, and optimized), and subprocesses were analyzed in pairs to compare the best stages between the two companies. The process for measuring productivity is detailed in the methodology.

Table 5 presents the list of management criteria for each subprocess.

Maturity diagnosis identified weaknesses, allowing for the implementation of continuous improvement focused on processes and employee development, which resulted in standardization and improvement in the execution of duplicated activities, and thereby a reduction in the time taken to meet deadlines.

According to Bowersox and Closs [42], the movement of materials is not limited to moving, boxing, and storage, but extends to the performance of these functions, considering the available time and space. Production support activities should not be considered as standalone procedures but should be integrated into the activity system to maximize the total productivity of the facility or warehouse. 
Table 5. List of subprocess management criteria.

\begin{tabular}{|c|c|}
\hline Criteria List & Description of Subprocess Characteristics \\
\hline $\begin{array}{l}\text { Documentation and Process } \\
\text { Management }\end{array}$ & $\begin{array}{c}\text { Flowchart } \\
\text { Standard operational procedure } \\
\text { Clear and well-communicated objectives } \\
\text { corporate policies }\end{array}$ \\
\hline Result Monitoring & $\begin{array}{l}\text { Result indicators } \\
\text { Reliable database with the historical performance of indicators }\end{array}$ \\
\hline Continuous Improvement & $\begin{array}{l}\text { Continuous improvement culture } \\
\text { Action plan culture } \\
\text { New technologies used in the last year }\end{array}$ \\
\hline Training and Qualification & $\begin{array}{l}\text { Structured training } \\
\text { Understanding the impact of individual work on the result }\end{array}$ \\
\hline
\end{tabular}

The centralization of processes allowed for financial gains with a reduction in overtime through the replacement of inefficient technologies that generated manual work and low productivity, as shown in Table 6.

Table 6. Financial gains with reduced overtime.

\begin{tabular}{ccc}
\hline Area & Previous Monthly Cost & Current Monthly Cost \\
\hline Procurement & 351.46 & 175.73 \\
\hline $\begin{array}{c}\text { Accounts payable, accounts receivable } \\
\text { and treasury }\end{array}$ & 580.90 & 290.45 \\
\hline Invoicing/billing & 633.93 & 316.96 \\
\hline Accounting & 577.98 & 288.99 \\
\hline Tax & 1245.83 & 622.91 \\
\hline Human resources & 1493.45 & 746.73 \\
\hline Information technology & 2497.57 & 1248.79 \\
\hline Fleet management & 4.65 & 2.32 \\
\hline Total & 7385.75 & 3692.88 \\
\hline
\end{tabular}

Technological innovation and the implementation of agile systems contributed to the fulfillment of the stipulated working hours and better remote-working conditions, reducing by $50 \%$ the monthly costs with overtime arising from manual activities and conferences.

Planet: Company B has a constantly renewed fleet and, as of November 2019, it started operating in-house, working directly at the plant of one of its large customers with a team allocated to the factory. The management unification of this operation brought synergy and dynamism to the operation, promoting a significant environmental gain.

In this way, the merger with Company B contributes to the achievement of Sustainable Development Goals 9.4, 11.6, and 13.1, as stipulated by the UN.

During the first 30 days of operation, there was a $40 \%$ reduction in the number of trips compared to the previous model, bringing a reduction of $37.4 \%$ in $\mathrm{CO} 2$ emissions, equivalent to less than five tons of pollutants deposited in the environment, whose neutralization would require the planting of 39 trees.

This achievement of Sustainable Development Goals 9.4, 11.6, and 13.1, as stipulated by the UN, are found in the sustainable management of the supply chain (SSCM), which, according to Mageto [43] has received much attention due to a greater awareness about global climate change and environmental and social issues. In addition, Herrmann et al. [47] reported that, in recent years, around $70 \%$ of leading companies in any given sector have emphasized sustainable development in their work programs. 


\subsection{Value Creation}

Key stakeholders: A network of experienced and qualified partners and suppliers in all solutions developed for customers. As they are outsourced services from delivery to satisfaction, offered services generate value for the products of the logistics company's customers.

Key activities: Innovative digital technologies. After the merger, all processes became automated, especially the accounts-receivable and invoicing of Company A, which started to use the methodology of Company B due to its more advanced maturity in its processes.

In this way, the merger with Company B contributed to achieving Sustainable Development Goal 8.2, as stipulated by the UN.

The integrated packaging, labeling, storage, and control solutions offered customers additional advantages, such as delivery and collection systems carried out by its fleet, detailed monitoring of the order cycle, specialized third-party management and related services, cargo tracking, and transport routes.

The implemented innovative digital technologies allow the acquiring company to develop sustainable innovation, which can be defined as the introduction of novelties or modifications in production processes, techniques, systems, organizations, and products to reduce environmental damage [58].

Key Resources and Capabilities: Experienced and continuously trained professionals make up experienced and qualified teams throughout the entire supply chain. The acquired company has a training and people development center, initially conceived to meet the company's training demand, which later evolved and opened its doors to the market.

Table 7 shows the investment costs for the continuous improvement of supervisors, coordinators, and full analysts.

Table 7. Map of investments in continuous improvement.

\begin{tabular}{cccc}
\hline Category & Type & Frequency & Monthly Investment \\
\hline $\begin{array}{c}\text { Continuous } \\
\text { improvement-supervisor/coordinator }\end{array}$ & OPEX & Recurrent & 7456.97 \\
\hline Continuous improvement-full analyst & OPEX & Recurrent & 3780.63 \\
\hline
\end{tabular}

\subsection{Delivery of Value}

Relationship with customers: Development of customized strategies that include demand planning and stock replenishment, designing streamlined and efficient operation and coordination networks with specific consultants for each project, customizing processes to customer needs.

Customer segment: Operating under the integrated management model, the merger provides more adequate solutions for each customer segment in both the B2B and the B2C segments. Company A has specialized activities in e-commerce, customization of projects with economical and profitable solutions, fashion and retail, cosmetics, telecoms, education, and banks and payment methods (specialized services of storage, handling, technical assistance, picking, packing, shipping, door to door distribution, courier, reverse logistics, squeegees, and stockings). Company B operates in the fractional and air B2B segments. With the merger, Company $\mathrm{A}$ includes all services and distribution for the Brazilian consumer and finished product market, reinforcing the last-mile operations for companies and points of sale.

Channels: An omnichannel service in which all distribution channels are integrated. Company B offers an online download of deliveries. The driver, in real time, through applications that are used on cell phones or the tracking system itself, informs the customer that the delivery was carried out, allowing customers to quickly obtain information. Company $B$ also offers access to all information related to the cargo, such as the collection position, distribution, deadlines, occurrences, and proof of delivery, in addition to the traceability of the goods by the cargo recipient. 


\subsection{Value Capture}

Cost structure: From the centralization of activities in the chosen areas of Companies $\mathrm{A}$ and $\mathrm{B}$ and the implementation of new technologies, Company A was able to reduce costs with employees and with the management teams of the areas, as shown in Tables 8 and 9.

Table 8. Benefits with employee resizing.

\begin{tabular}{ccc}
\hline Employee Resizing & Costs before Centralization & Costs after Centralization \\
\hline Procurement & $39,757.71$ & $34,747.10$ \\
\hline Accounts payable & $27,136.62$ & $16,042.28$ \\
\hline Accounts receivable & $31,071.34$ & $22,565.41$ \\
\hline Treasury & 8990.89 & 5492.52 \\
\hline Invoicing/billing & $59,470.48$ & $38,972.65$ \\
\hline Accounting & $48,084.69$ & $27,748.79$ \\
\hline Tax & $89,889.13$ & $62,612.43$ \\
\hline Human resources & $66,218.02$ & $54,438.02$ \\
\hline Information technology & $90,713.44$ & $70,751.33$ \\
\hline Fleet management & $17,984.47$ & 6816.75 \\
\hline Total & $479,316.79$ & $340,187.27$ \\
\hline
\end{tabular}

Table 9. Benefits from resizing management teams.

\begin{tabular}{ccc}
\hline Management Teams Resizing & Costs before Centralization & Costs after Centralization \\
\hline Procurement & $14,168.24$ & $14,168.24$ \\
\hline $\begin{array}{c}\text { Accounts payable, accounts } \\
\text { receivable, treasury and } \\
\text { invoicing/billing }\end{array}$ & $85,895.59$ & $64,200.16$ \\
\hline Accounting & $35,863.68$ & $35,863.68$ \\
\hline Tax & $44,424.70$ & $21,695.43$ \\
\hline Human resources & $28,336.49$ & $28,336.49$ \\
\hline Information technology & $50,031.92$ & $50,031.92$ \\
\hline Fleet management & $48,549.65$ & $26,854.22$ \\
\hline Total & $307,270.27$ & $241,150.14$ \\
\hline
\end{tabular}

Centralization allowed for the improvement of integrated logistics that, according to Ballou [40], has been strengthened in the rationalization of operating costs, improvement of services, and change in the environment, promoting global logistics and strategic organizational growth.

Revenue stream: as financial parameters, a K factor of 1.9 (ratio between the total cost of a worker and the amount paid to the same worker as remuneration) and an annual weighted average cost of capital (WACC) of 18 were used $(0.37 \%$ return on investment related to process centralization).

Through the elaboration of cash flows, the financial data of the centralization of the processes were obtained and are presented in Table 10.

According to Table 10, the payback (return on investments) in the centralization of areas and the optimization of activities is 15 months, considering the beginning of centralization in August 2020 and the investment in improvements, which was in the order of $2,098,650.02$. 
Table 10. Financial data from process centralization.

\begin{tabular}{cccc}
\hline \multicolumn{2}{c}{ Financial Indicators } & \multicolumn{2}{c}{ Compression and Investiments } \\
\hline NPV (3 years) & $2,263,522.28$ & Compression-Staff & $29 \%$ \\
\hline NPV (5 years) & $4,858,040.73$ & Compression-Management & $22 \%$ \\
\hline IRR (5 years) & $8.5 \%$ & Cost Reduction & $26 \%$ \\
\hline PAYBACK & Feb 2022 & CAPEX & $2,098,650.02$ \\
\hline
\end{tabular}

The results of the data show that there was an improvement in the efficiency of activities, through the union of processes and technologies, as well as a reduction in costs through the resizing of employees. In addition, the number of overtime hours was reduced, allowing for a better quality of work for those involved.

Improving supply chain performance represents the biggest cost-saving advantage, especially in the context of horizontal consolidation [62-64].

\section{Conclusions}

We identified how the merger of two Brazilian logistics companies targeting different customers could positively contribute to sustainability, considering social and environmental aspects. This identification was made possible at first by using the Canvas business model to map the internal areas involved. Subsequently, the results were applied to the Canvas sustainable business model, identifying social and environmental aspects.

Through a descriptive exploratory case study, it was possible to analyze a unified sustainable business model, simultaneously identifying some of the 17 Sustainable Development Goals stipulated by the UN in the 2030 agenda.

The sustainable business model canvas was a tool for understanding and merging the two B2B and B2C business models of each company. The elements of profit, people, and planet incorporated into the canvas' conceptual business model allowed for a holistic view that considers some sustainable challenges stipulated by the UN, such as Goals 9.4 (modernize infrastructure and rehabilitate industries to make them sustainable, with increased efficiency in use resources and greater adoption of clean and environmentally friendly technologies and industrial processes; with all countries acting in accordance with their respective capabilities), 13.1 (enhance resilience and adaptive capacity to climaterelated risks and natural disasters in all countries), 11.6 (reduce the per capita negative environmental impact of cities by 2030, including paying special attention to air quality and municipal waste management), and 8.2 (achieve higher levels of productivity in economies through diversification, technological modernization, and innovation, including through a focus on high value-added and labor-intensive sectors).

The triple baseline (TBL) in the sustainability of environmental, social, and economic dimensions can be analyzed through the sustainable canvas business model, through the elements of planet, people, and profit, respectively.

Some data obtained after the merger stand out: after centralization and unification, centralized productivity had an average growth of $8 \%$, considering duplicated activities; the centralization of processes allowed for financial gains with a reduction in overtime through the replacement of inefficient technologies that generated manual work and low productivity. Technological innovation and the implementation of agile systems contributed to the fulfillment of the stipulated working hours and better remote-working conditions, reducing by $50 \%$ the monthly costs with overtime arising from manual activities and conferences. Another positive fact is the $40 \%$ reduction in the number of trips made compared to the previous model, bringing a $37.4 \%$ reduction in $\mathrm{CO}_{2}$ emissions.

It was possible to diagnose the improvement in corporate social performance and the integration of sustainability into companies' business practices.

It was, however, not possible to compare the obtained data with other surveys to measure the optimization of processes involving people, technology, and environmental 
sustainability, as the research was limited to analyzing a case study involving the merger of two logistics companies.

The merger allowed for market diversification as a result of the combination of $\mathrm{B} 2 \mathrm{~B}$ and B2C models, better serving the customers that make up the market segment. The expansion of the market allowed for an increase in revenues and an internal rate of return of $8.5 \%$ per year.

For future research, sustainable business models of companies with different production systems that are in the merger and acquisition process should be analyzed.

Author Contributions: Conceptualization, M.T.O. and J.G.C.G.; methodology, M.T.O.; software, M.E.F.; validation, M.T.O., H.C.L.d.S. and M.E.F.; formal analysis, R.S.G. and J.G.C.G.; investigation, J.G.C.G.; resources, M.T.O.; data curation, M.T.O.; writing-original draft preparation, J.G.C.G.; writing—review and editing, D.d.S.C. and M.T.O.; translation, D.d.S.C.; visualization, H.C.L.d.S.; supervision, M.T.O.; project administration, M.T.O. and J.G.C.G.; funding acquisition, R.S.G. and J.G.C.G. All authors have read and agreed to the published version of the manuscript.

Funding: This research received no external funding.

Institutional Review Board Statement: Not applicable.

Informed Consent Statement: Not applicable.

Data Availability Statement: Not applicable.

Conflicts of Interest: The authors declare no conflict of interest.

\section{References}

1. Doleski, O.D. Integrated Business Model: Applying the St. Gallen Management Concept to Business Models; Springer: Berlin/Heidelberg, Germany, 2015; pp. 4-10.

2. Lehong, H.; Swanton, B. A Digital Business Technology Platform Is Fundamental to Scaling Digital Business; Gartner Inc.: Stamford, CT, USA, 2017.

3. Silva, M.E.D.; Neutzling, D.M.; Alves, A.P.F.; Dias, P.; Santos, C.A.F.D.; Nascimento, L.F.M.D. Gestão da Cadeia de Suprimentos Sustentável: Entendendo o Discurso Brasileiro. 2013. Available online: http://repositorio.furg.br/handle/1/6371 (accessed on 1 May 2021).

4. da Rocha, A.C.; Gomes, C.M.; Kneipp, J.M.; Camargo, C.R. Gestão Sustentável da Cadeia de Suprimentos e Desempenho Inovador: Um estudo multicaso no setor mineral brasileiro. RAI Rev. De Adm. E Inovação 2015, 12, 293-316. [CrossRef]

5. Osterwalder, A.; Pigneur, Y.; Tucci, C.L. Clarifying business models: Origins, present, and future of the concept. Commun. Assoc. Inf. Syst. 2005, 16, 1. [CrossRef]

6. Osterwalder, A.; Pigneur, Y. Business Model Generation: A Handbook for Visionaries, Game Changers, and Challengers; John Wiley \& Sons: Hoboken, NJ, USA, 2010; Volume 1.

7. Bocken, N. Sustainable Business Models. In Decent Work and Economic Growth. Encyclopedia of the UN Sustainable Development Goals; Leal Filho, W., Azul, A.M., Brandli, L., Lange Salvia, A., Wall, T., Eds.; Springer: Cham, Switzerland, 2021. [CrossRef]

8. Gupta, P.K. Mergers and acquisitions (M\&A): The strategic concepts for the nuptials of corporate sector. Innov. J. Bus. Manag. 2012, 1, 60-68.

9. Kneipp, J.M.; Gomes, C.M.; Kruglianskas, I.; Motke, F.D.; Frizzo, K. Sustainable innovation practices and the degree of innovation of business models in Brazilian industrial companies. World J. Sci. Technol. Sustain. Dev. 2021, 18, 221-238. [CrossRef]

10. Gil, A.C. Como Elaborar Projetos de Pesquisa; Atlas: São Paulo, Brazil, 2017; Volume 4, p. 175.

11. Becker, W.; Ulrich, P.; Ebner, R.; Zimmermann, L. Erfolgsfaktoren der Geschäftsmodelle Junger Unternehmen; opus: Bamberg, Germany, 2012.

12. Gomes, J.G.C.; Okano, M.T.; Simões, E.A.; Otola, I. Management strategy and business models in the era of digital transformation. S. Am. Dev. Soc. J. 2019, 5, 252. [CrossRef]

13. Okano, M.T.; Antunes, S.; Langhi, C.; Simões, E. Digital Transformation: News Technologies and Business Model. Int. J. Sci. Res. Methodol. 2019, 13, 81-100.

14. Beltramello, A.; Haye-Fayle, L.; Pilat, D. Why New Business Models Matter for Green Growth; OECD Publishing: Paris, France, 2013.

15. Teece, D. Business model, business strategy, and innovation. Long Range Plan. 2010, 43, 172-194. [CrossRef]

16. Carvalho, C.; Rego, C.; Lucas, M.R.; Sánchez-Hernández, M.I.; Viana, A.B.N. New Paths of Entrepreneurship Development; Springer International Publishing: Berlin/Heidelberg, Germany, 2019.

17. Teece, D.J.; Linden, G. Business models, value capture, and the digital enterprise. J. Organ. Des. 2017, 6, 6-8. [CrossRef]

18. Otola, I.; Grabowska, M.; Szajt, M. Value Composition for Business Models of High-Growth Enterprises. In Business Models, 1st ed.; Otola, I., Grabowska, M., Eds.; Auerbach Publications: Boca Raton, FL, USA, 2020; pp. 33-48. 
19. Alegre, I.; Berbegal-Mirabent, J. Social innovation success factors: Hospitality and tourism social enterprises. Int. J. Contemp. Hosp. Manag. 2016, 28, 1155-1176. [CrossRef]

20. Bocken, N.M.P.; Short, S.W.; Rana, S.; Evans, S. A literature and practice review to develop sustainable business model archetypes J. Clear. Prod. 2014, 65, 42-56. [CrossRef]

21. Geissdoerfer, M.; Vladimirova, D.; Evans, S. Sustainable business model innovation: A review. J. Clean. Prod. 2018, 198, 401-416. [CrossRef]

22. Jacob, A.; Teuteberg, F. Towards a Taxonomy for Design Options of Social Networking Technologies in Sustainable Business Models. Sustainability 2020, 13, 81. [CrossRef]

23. Heirman, K.A.; Gill, J.C.; Caven, S. Decent Work and Economic Growth. In Geosciences and the Sustainable Development Goals; Springer: Berlin/Heidelberg, Germany, 2021; pp. 183-207.

24. Frank, A.G.; Mendes, G.H.; Ayala, N.F.; Ghezzi, A. Servitization and Industry 4.0 convergence in the digital transformation of product firms: A business model innovation perspective. Technol. Forecast. Soc. Change 2019, 141, 341-351. [CrossRef]

25. Nascimento DL, M.; Alencastro, V.; Quelhas OL, G.; Caiado RG, G.; Garza-Reyes, J.A.; Rocha-Lona, L.; Tortorella, G. Exploring Industry 4.0 technologies to enable circular economy practices in a manufacturing context: A business model proposal. J. Manuf. Technol. Manag. 2019, 30, 607-627. [CrossRef]

26. Müller, J.M.; Buliga, O.; Voigt, K.I. The role of absorptive capacity and innovation strategy in the design of industry 4.0 business Models-A comparison between SMEs and large enterprises. Eur. Manag. J. 2021, 39, 333-343. [CrossRef]

27. Müller, J.M.; Buliga, O.; Voigt, K.I. Fortune favors the prepared: How SMEs approach business model innovations in Industry 4.0. Technol. Forecast. Soc. Change 2018, 132, 2-17. [CrossRef]

28. Müller, J.M.; Däschle, S. Business model innovation of industry 4.0 solution providers towards customer process innovation. Processes 2018, 6, 260. [CrossRef]

29. Franceschelli, M.V.; Santoro, G.; Candelo, E. Business model innovation for sustainability: A food start-up case study. Br. Food J. 2018, 120, 2483-2494. [CrossRef]

30. Ray, A.; Mondal, S. Study of collaborative PRM business model for sustainability. Benchmarking Int. J. 2017, 24, 891-1911. [CrossRef]

31. Osterwalder, A. The Business Model Ontology: A Proposition in a Design Science Approach. 2004. Available online: https: / / patrinum.ch/record/15985/usage (accessed on 1 May 2021).

32. Burkett, I. Using the Business Model Canvas for Social Enterprise Design. 2013. Available online: http://knode.com.au/wpcontent/uploads/Knode_BusModCanv4SocEntDesign_E1LR_30p.pdf (accessed on 1 May 2021).

33. Orofino, M. Técnicas de Criação do Conhecimento no Desenvolvimento de Modelos de Negócio. Master's Thesis, Centro Tecnológico, Programa de Pós-Graduação em Engenharia e Gestão do Conhecimento, Universidade Federal de Santa Catarina, Florianópolis, Brazil, 2011.

34. Bocken, N.; Schuit, C.; Kraaijenhagen, K. Experimenting with a circular business model: Lessons from eight cases. Environ. Innov. Soc. Transit. 2018, 28, 79-95. [CrossRef]

35. Richardson, J. The business model: An integrative framework for strategy execution. Strateg. Change 2008, 17, 133-144. [CrossRef]

36. Arredondo, C.R.; Tanco, J.A.A. Supply Chain Management: Some Reflections to Improve its Influence in Business Strategy. Innovar 2021, 31, 7-19. [CrossRef]

37. United Nations in Brazil. Os Objetivos de Desenvolvimento Sustentável no Brasil. Available online: https://brasil.un.org/pt-br/ about/about-the-un (accessed on 20 March 2021).

38. Aguezzoul, A. Third-party logistics selection problem: A literature review on criteria and methods. Omega 2014, 49, 69-78 [CrossRef]

39. Copacino, W.C. Supply Chain Management: The Basics and Beyond; St Lucie Press: Boca Raton, FL, USA, 1997.

40. Ballou, R.H. Gerenciamento da Cadeia de Suprimentos, Logística Empresarial; Bookman: Porto Alegre, Brazil, 2010.

41. Júnior, C.M.; Ribeiro DM, N.M.; da Rocha, C.A.; Mazzali, L.; Palmisano, A. Bases de integração entre um operador logístico e seus fornecedores. Gestão Reg. 2018, 34. [CrossRef]

42. Bowersox, D.J.; Closs, D.J. Logística Empresarial, o Processo de Integração da Cadeia de Suprimentos; Atlas: São Paulo, Brazil, 2010.

43. Mageto, J. Big data analytics in sustainable supply chain management: A focus on manufacturing supply chains. Sustainability 2021, 13, 7101. [CrossRef]

44. Green, K.W., Jr.; Zelbst, P.J.; Meacham, J.; Bhadauria, V.S. Green supply chain management practices: Impact on performance. Supply Chain Manag. Int. J. 2012, 17, 290-305. [CrossRef]

45. Carter, C.R.; Rogers, D.S. A framework of sustainable supply chain management: Moving toward new theory. Int. J. Phys. Distrib. Logist. Manag. 2008, 38, 360-387. [CrossRef]

46. Seuring, S.; Muller, M. From a literature review to a conceptual framework for sustainable supply chain management. J. Clean. Prod. 2008, 16, 1699-1710. [CrossRef]

47. Herrmann, F.F.; Barbosa-Povoa, A.P.; Butturi, M.A.; Marinelli, S.; Sellitto, M.A. Green Supply Chain Management: Conceptual Framework and Models for Analysis. Sustainability 2021, 13, 8127. [CrossRef]

48. de Sousa Jabbour, A.B.L. Understanding the genesis of green supply chain management: Lessons from leading Brazilian companies. J. Clean. Prod. 2015, 87, 385-390. [CrossRef] 
49. Jabbour, A.B.L.D.S.; Jabbour, C.J.C.; Latan, H.; Teixeira, A.A.; de Oliveira, J.H.C. Quality management, environmental management maturity, green supply chain practices and green performance of Brazilian companies with ISO 14001 certification: Direct and indirect effects. Transp. Res. Part E Logist. Transp. Rev. 2014, 67, 39-51. [CrossRef]

50. Elkington, J. Towards the sustainable corporation: Win-win-win business strategies for sustainable development. Calif. Manag. Rev. 1994, 36, 90-100. [CrossRef]

51. Kim, D.; Kim, S. Sustainable supply chain based on news articles and sustainability reports: Text mining with Leximancer and Diction. Sustainability 2017, 9, 1008. [CrossRef]

52. Pagell, M.; WU, Z. Building a More Complete Theory of Sustainable Supply Chain Management Using Case Studies of 10 Exemplars. J. Supply Chain. Manag. 2009, 45, 37-56. [CrossRef]

53. Van Bommel, H.W.M. A conceptual framework for analyzing sustainability strategies in industrial supply networks from an innovation perspective. J. Clean. Prod. 2011, 19, 895-904. [CrossRef]

54. Matos, S.; Silvestre, B.S. Managing stakeholder relations when developing sustainable business models: The case of the Brazilian energy sector. J. Clean. Prod. 2013, 45, 61-73. [CrossRef]

55. Jabłonski, M. Kształtowanie Modeli Biznesu w Procesie Kreacji Wartości Przedsiębiorstw; Difin: Warszawa, Poland, 2013.

56. Evans, S.; Vladimirova, D.; Holgado, M.; Van Fossen, K.; Yang, M.; Silva, E.A.; Barlow, C.Y. Business model innovation for sustainability: Towards a unified perspective for creation of sustainable business models. Bus. Strategy Environ. 2017, 26, 597-608. [CrossRef]

57. Norris, S.; Hagenbeck, J.; Schaltegger, S. Linking sustainable business models and supply chains-Toward an integrated value creation framework. Bus. Strategy Environ. 2021, 30, 3960-3974. [CrossRef]

58. Kusi-Sarpong, S.; Gupta, H.; Sarkis, J. A supply chain sustainability innovation framework and evaluation methodology. Int. J. Prod. Res. 2019, 57, 1990-2008. [CrossRef]

59. González-Torres, T.; Rodríguez-Sánchez, J.-L.; Pelechano-Barahona, E.; García-Muiña, F.E. A Systematic Review of Research on Sustainability in Mergers and Acquisitions. Sustainability 2020, 12, 513. [CrossRef]

60. Makri, M.; Hitt, M.A.; Lane, P.J. Complementary technologies, knowledge relatedness, and invention outcomes in high technology mergers and acquisitions. Strat. Manag. J. 2009, 31, 602-628. [CrossRef]

61. Cartwright, S.; Schoenberg, R. Thirty Years of Mergers and Acquisitions Research: Recent Advances and Future Opportunities. Br. J. Manag. 2006, 17, S1-S5. [CrossRef]

62. Gupta, S. Mergers and Acquisitions for Enhancing Supply Chain Competitiveness. J. Mark. Oper. Manag. Res. $2012,2,129-147$.

63. Inderst, R.; Shaffer, G. Retail Mergers, Buyer Power and Product Variety. Econ. J. 2007, 117, 45-67. [CrossRef]

64. Cho, S.-H. Horizontal Mergers in Multitier Decentralized Supply Chains. Manag. Sci. 2014, 60, 356-379. [CrossRef]

65. Yin, R.K. Estudo de Caso-Planejamento e Métodos; Bookman Editora: Porto Alegre, Brazil, 2015.

66. Langley, A. Strategies for Theorizing from Process Data. Acad. Manag. Rev. 1999, 24, 691-710. [CrossRef]

67. Fenton, C.; Langley, A. Strategy As Practice And The Narrative Turn. Organ. Stud. 2011, 32, 1171-1196. [CrossRef] 